\title{
On the Adrenalin Hyperglycemia.
}

The First Report. The Relation of Adrenalin to the Change of the Glycogen Content in the Muscle.

By

TOSHIO OHARA.

(小原 敏 雄)

(From Prof. T. Kumagai's Medical Clinic, Tohoku

Imperial University, Sendai, Japan.)

\section{INTRODUCTION.}

The most interesting and noteworthy of all the effects of adrenalin is the power which causes hyperglycemia and glycosuria. This is the reason why we find in literature so many reports on this subject. Adrenalin hyperglycemia, generally speaking, is not only one of the most typical experimental hyperglycemia but also bears a direct or indirect relation, as the case may be, with other experimental hyperglycemia in question and scemingly takes its position in the very centre of all others in importance.

Blum, in 1901, discovered that the subcutaneous injection of adrenal extract developed glycosuria, and he found that such extracts given by the mouth had no influence. He concluded from a series of 22 experiments that suprarenal extract when given subentaneously causes marked glycosuria not only on diet free of carbuhydrates but also after a fast for 14 days. In his second paper he recorded some experiments upon adrenalin diabetes and confirmed that repeated injections of adrenalin in increasing dose produced glycosuria.

Zuelzer"' confirmed Blum in all particulars and found an inerease of sugar in the blood.

Metzge $\mathrm{r}^{4}$ proved that adrenalin glycosuria is due to an increase in the glucose of the blood.

Herter and Richards reported that prolonged fasting with phloridzin injection redured a dog to a condition in which the injection of adrenalin resulted no glycosuria. 
In the second paper, Herter and $\mathrm{Wakeman}^{6}$ reported the results of further experiments, which do not fully consist with the previous assertions.

It was proved by Vosburgh, Richards $s^{7)}$ and by Iwa roff ${ }^{\text {s) }}$ that adrenalin glycosuria is the result of an overproduction of dextrose, in consequence of an accelerated breaking down of glycogen in the body. Macleod and Pearce proved that injection of epinephrine into the portal circulation of a living animal is followed by increased glycogenolysis in the liver.

Zuelzer ${ }^{1011)}$ found that when the liver of $\operatorname{dog}$ is perfused with dog-blood, the sugar content of the perfused blood is increased.

But Starkenstein, ${ }^{12}$ ) perfusing the normal liver with salt solution or defibrinated blood, found no influence of the addition of adrenalin to the perfusion fluid upon the rate of disappearance of glycogen.

Noel-Paton, ${ }^{13}$ after adrenalin injection, found no change in the protein metabolism of well-fed animals, but in insufficiently nourished dogs he observed an increase in the nitrogen excretion and he declined to consider the adrenalin glycosuria in fasting animals as a result of sugar formation from albumin.

Eppinger, Falta and Rudinger ${ }^{1+15)}$ found that depancreatized dogs, supposed to be practically glycogen-free, showed increase of sugar formation under the influence of adrenalin.

Ringer ${ }^{16)}$ considered the depancreatized animals to be not glycogenfree, and he made dogs glycogen-free by a combination of hunger, cold and phloridzin and then found that administration of adrenalin produced no increase in the elimination of sugar and no change in the dextrose-nitrogen ratio $(\mathrm{D}: \mathrm{N})$.

Doyon and Kareff, ${ }^{17}$ Wolownik ${ }^{18)}$ and many others consider that the liver glycogen is the source of the sugar eliminated by injection of adrenalin. Since then even until today, numberless reports of this kind of observations have been made public one after another.

As these reports, for the most part, have been on the relation of adrenalin glycosuria either to the liver, the pancreas or to the adrenal, matters in these lines are naturally rendered quite intelligible so that the general acceptance is that adrenalin produces hyperglycemia and glycosuria by acting upon glycogen in the liver. Therefore, if the liver or glycogen in the liver be completely vanished, there adrenalin glyoosuria can never be produced anymore.

Falta and Priestley (1911), ${ }^{19)}$ in order to ascertain that sugar in 
the blood increased by adrenalin is entirely to be attributed to the liver, ligated, following the Porges' method, all the blood vessels right below the diaphragm, and after they removed the liver and chromaffin system entirely out of the metabolism, they injected adrenalin into the anterior part of the body. And then they found not only that hyperglyeemia was no more produced thereby but that the blood sugar content progressively got lowered too. In the case of normal animals, after they were injected 3 mgrms. of adrenalin, remarkable hyperglycemia from 0.27 to $0.35 \%$ was developed, while on the contrary, in the animals operated upon the blood sugar remained no more than $0.04 \% \%$ in 39 minutes after the injection of the same dose and no other symptom appeared. Judging from the results of these experiments they conchuded that adrenalin hyperglycenia had much to do with only glycogen in the liver, but nothing with glycogen in muscle at all.

Frank and Isaac's ${ }^{20 y}$ experiments, in which though they injected adrenalin into phosphorus-poisoned rabbits they could not observe any sign of adrenalin hyperglycemia developed, made them affirm that it might be that the adrenalin injection resulted in hyperglycemia, only as long as the liver was able to work its carbohydrate synthesis.

Michaud, ${ }^{21}$ in like manner, made use of phosphorus-poisoned dogs in the similar experiments in which he could notice the existence of the blood sugar only of $0.059 \% 0-0.044 \% 6$ after an injection of $8 \mathrm{mgrms}$. of adrenalin.

Of all experiments like those above mentioned, that of Mieh a 1 ( $^{21}$ on Eck's fistula-dog is frequently quoted. According to Mich a ud's report, the subcutaneous injection of 8-10 mgrms. of adrenalin resulted in hyperslycemia from the minimum of $0.157 \% 6$ to the maximum of $0.253 \%$ in the case of normal dogs. In Eck's fistula, on the other hand, the applieation of the same dose of adrenalin caused no hyperglycemia. To make the matter much clearer, in one case the blood sugar showed $0.08 \%$, in the second $0.08 \%$ and $0.073 \%$, and in the third $0.116-0.105 \%$ with only one cxception of hyperglycemia of $0.245 \%$. In all the cascs, there was no single instance in which distinct glyosuria was developed. And therefore Mich aud concluded that as adrenalin was capable of producing hyperglycemia as long as the liver, namely the principal glycogen store, was placed at the disposal, if this glycogen storeroom be cut off from the portal circulation, carbohydrate will never be poured ont into the circulation and consequently neither hyperglyecmia nor glycosuria will be caused. But T. Oka's ${ }^{22)}$ work on the Eck fistula dogs showed a quite different result as that of Michaud. 
And on the other hand, the following facts must be taken into consideration.

1. That there are quite many instances in which even though the liver be cut off from the circulation, the blood sugar never entircly disappears thereby. Even in the specimen of the blood taken from animals in morbid condition the existence of the blood sugar can be evidently proved.

2. That Eck's fistula-dogs can live without any serious disturbance of carbohydrate metabolisn.

3. That so far as the percentage is concerned the glycogen content in muscle stands lower than that of the liver, but with regard to the total amount it can favorably compare with the latter.

4. That the most part of the sugar which burns in the organism burns in muscle.

Gatin-Gruzewska, ${ }^{23)}$ making use of rabbits, observed that not only the glycogen in liver but also that in muscle disappeared in 36-40 hours when the rabbits, that had been kept fasting for one day, underwent the intraperitoneal injection of adrenalin in doses of $1 \mathrm{mgrm}$. or less per kilo of body weight.

The complete disappearance of the muscle glycogen in rabbits, fasted and poisoned with adrenalin, was also reported by $\mathrm{Aga} \mathbf{r d s c h}$ anianz. ${ }^{2+1}$ Starkenstein ${ }^{25}$ observed that rabbits after adrenalin injection excrete the sugar more than the loss of the glycogen in the liver.

Bang ${ }^{26)}$ announced that adrenalin hyperglycemia in fasted rabbits is high as in well-fed rabbits, and he attributed it to the breaking down of glycogen other than that of the liver. But he considers that the liver is indispensable for adrenalin hyperglycemia, and the liver glycogen is the source of it.

These results of the observations and facts are enough to make us suppose that beside the liver there must be some other organ which can support carbohydrate metabolism, and that glycogen contained in muscle is in some way or other related to carbohydrate metabolism just as glycogen in the liver is. Therefore it is necdless to say that the effort to make this relation clear naturally turns ont to be the most important contribution to the researches for carbohydrate metabolism. With the view of observing whether adrenalin is able to produce hyperglycemia by directly affecting muscle glycogen or not, I have tried various ways and methods and ablated the liver out of circulation on one hand, and diminished glycogen in the liver on the other. Then adrenalin injection 
was made into these animals, and in order to observe the course of the adrenalin hyperglycemia, the sugar content in the blood was estimated at regular intervals, and was put under exact comparison. The animals used in these experiments of mine were mostly rabbits, dogs being used in the other and very few cases.

\section{Experimentai Results.}

\section{Experiments on the Fasting Animals.}

For the purpose of bringing about the consumption of glycogen in the liver, I made use of animals which had been kept fasting for 6-10 days. Before the adrenalin injection I applied the Esmarch's elastic bandage to one of the animal's hind legs, and amputated it at the groin, and I made an immediate estimation of the amount of glycogen in the muscle. Then, after the lapse of certain time after the adrenalin injection, I did the same thing with the other hind leg in amputating it and in cstimating the amount of glycogen in its muscle too. And then, I compared these two estimates of glycogen each other. At the same time, the blood sugar after the lapse of certain time was estimated.

The method that I adopted to make the estimates of the amount of glycogen was as follows. It is a slight modification of the Pflüger's method.

I heated the pap of tissues at $120^{\circ} \mathrm{C}$ for half an hour, in an autoclare with $35 \mathrm{~g} / \mathrm{dl}$ of caustic potassium solution and it was reduced into fluidal state. And when it got cool, I added to it twice its quantity of alcohol $(96 \%)$ and kept it quiet for twenty-four hours to cause glycogen in it to precipitate. I gathered the precipitated glycogen on a piece of filter-paper, washed with $66 \%$ alcohol until the filtrate is quite colourless, then dissolved it by pouring suitable amount of boiling water. Inpure mixture and coloured matter were removed by dropping one drop or two of hydrochloric acid into it. And the solution was poured into a volumctric flask and carried up to the mark with distillet water and filtered. Then I estimated glycogen in the solution thus obtained by means of the polarimeter or I inverted all the glycogen into glucose by pouring hydrochloric acid at the rate of 2.5 per cent into this solution, and by heating it again in an autoclave at $120^{\circ} \mathrm{C}$ for half an hour.

It may be properly mentioned here that I adopted both Pavy-Kumagawa-Suto's methol and Momoses molifination of it for the cstimation of sugar of urine and glyogen. And as for the estimation of sugar in the blood, I made use of the Bang's micromethod. 
In the experiment I to VIII, the left leg was previously amputated using Esmarch's elastic: bandage for expelling the blood from the limb. After the lapse of certain hours following subentaneous injection of adrenalin, the other hind leg was amputated in like manner. Then the glycogen content of each one was estimated and compared with the other.

\section{Experiment I.}

Dog 1. Male, fasting from January 7 to January 13, measured water ad libitum, initial weight 8.2 kilos, final weight 6.6 kilos at 2 p.m. January 13.0 .5 c.c. of adrenalin $(1: 1000)$ per kilo subcutaneously injected.

\begin{tabular}{|c|c|c|c|c|c|}
\hline \multicolumn{5}{|c|}{ Time of taking blood } & $\begin{array}{c}\text { Blood sugar } \\
0<\end{array}$ \\
\hline \multirow{2}{*}{\multicolumn{5}{|c|}{$\begin{array}{l}\text { Before adrenalin injection } \\
10 \text { minules atier atronalin iujectim }\end{array}$}} & 0.133 \\
\hline & & & & & 0.135 \\
\hline 15 & $"$ & ", & $"$ & $"$ & $0.1: 0$ \\
\hline 25 & $"$ & $"$ & $"$ & $"$ & 0.141 \\
\hline 30 & $"$ & $"$ & $"$ & $"$ & 0.148 \\
\hline 45 & $"$ & $"$ & " & $"$ & 0.149 \\
\hline 60 & $"$ & $"$ & " & ", & 0.161 \\
\hline 120 & $"$ & $"$ & $"$ & $"$ & 0.163 \\
\hline 180 & $"$ & ", & $"$ & $"$ & 0.163 \\
\hline
\end{tabular}

Maximum height $=$ initial figure $+22.6 \%$
Change in glycogen content.

\begin{tabular}{c|c}
\hline Remarks & $\begin{array}{c}\text { Glycogen } \\
\%\end{array}$ \\
\hline $\begin{array}{c}\text { Before adrenalin injection } \\
\text { Left hind leg muscles }\end{array}$ & 0.125 \\
$\begin{array}{c}\text { 3 hours after adrenalin } \\
\text { injection }\end{array}$ & \\
Right bind leg muscles & 0 \\
Lirer & 0 \\
Heart muscle & 0.134
\end{tabular}

(Dininution of glycogen in muscle

$100 \%)$

\section{Experiment II.}

Dog 2. Female, fasting from January 7 to January 14. Measured water ad libitum, initial weight $7.4 \mathrm{kilos}$, final weight $5.7 \mathrm{kilos}$ at 1 p.m. January $14 . \quad 0.5$ c.c. of adrenalin (1:1000) per kilo subcutaneously injected.

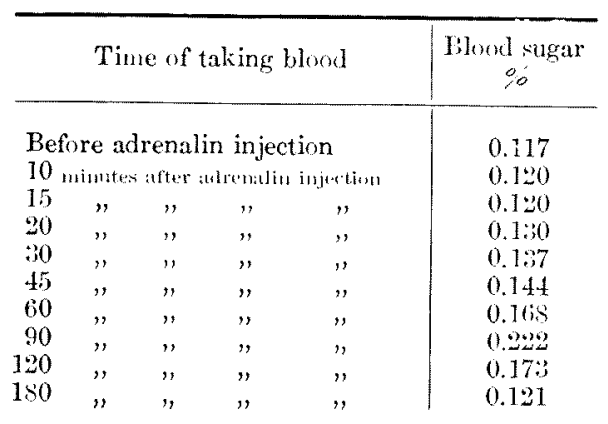

Maximum height $=$ initial figure $+90 \%$
Change in glycogen content.

\begin{tabular}{c|c}
\hline Remarks & $\begin{array}{c}\text { Glycogen } \\
\%\end{array}$ \\
\hline $\begin{array}{c}\text { Before adrenalin injection } \\
\text { Left hind leg muscles }\end{array}$ & 0.258 \\
3 hours after adrenalin & \\
injection & \\
Right hind leg muscles & 0.155 \\
Liver & 0.277 \\
Ireart nuscle & 0.205
\end{tabular}

(Diminution of glycogen in muscle $40 \%$ ) 


\section{Experiment III.}

Rabbit 1. Female fasting from January 24 to February 3. Water ad libitum, initial weight $2.2 \mathrm{kilos}$, final weight 1,6 kilos. at 1 p.m. February 3.1 c.c. of adrenalin $(1: 1000)$ subcutaneously injected.

\begin{tabular}{|c|c|c|c|c|c|}
\hline \multicolumn{5}{|c|}{ Time of taking blood } & $\begin{array}{c}\text { Blood sugar } \\
\%\end{array}$ \\
\hline \multicolumn{5}{|c|}{ Before adrenalin injection } & 0.120 \\
\hline \multicolumn{5}{|c|}{15 minutes after adrenalin injection } & 0.147 \\
\hline 30 & $"$ & $"$ & $"$ & " & 0.186 \\
\hline 60 & $"$ & " & $"$ & $"$ & 0.211 \\
\hline 120 & $"$ & $"$ & $"$ & $"$ & 0.239 \\
\hline 180 & $"$ & " & $"$ &, & 0.241 \\
\hline
\end{tabular}

Maximum height $=$ about twice of initial figure.
Change in glycogen content.

\begin{tabular}{c|c}
\hline Remarks & $\begin{array}{c}\text { Glycogen } \\
\%\end{array}$ \\
\hline $\begin{array}{c}\text { Before adrenalin injection } \\
\text { Left hind leg muscles }\end{array}$ & 0.666 \\
3 hours after adrenalin & \\
injection & \\
Right hind leg muscles & 0.229 \\
Liver & 0.238 \\
Heart muscle & 0.229
\end{tabular}

\section{Experiment IV.}

Rabbit 2. Male, fasting January 26 to February 1. Water ad libitum, initial weight $1.3 \mathrm{kilos}$, final weight $0,9 \mathrm{kilo}$, at 3 p.m. Febraury 1.1 c.c. of adrenalin $(1: 1000)$ subcutaneously injected.

\begin{tabular}{|c|c|c|c|c|c|}
\hline & \multicolumn{4}{|c|}{ Time of taking blood } & $\begin{array}{c}\text { Blood sugar } \\
\%\end{array}$ \\
\hline \multirow{2}{*}{\multicolumn{5}{|c|}{$\begin{array}{l}\text { Before adrenalin injection } \\
10 \text { minute: after adrenalin injection }\end{array}$}} & 0.117 \\
\hline & & & & & 0.120 \\
\hline 15 & $"$ & , & , & , & 0.120 \\
\hline 25 & ", & " & " & " & 0.130 \\
\hline 30 & $"$ & " & ", & , & 0.137 \\
\hline 45 & ", & ", & , & , & 0.144 \\
\hline 60 & ", & ") & " & $"$ & 0.120 \\
\hline 90 & , & , & ", & , & 0.122 \\
\hline 120 & $"$ & , & $"$ & , & 0.103 \\
\hline 180 & , & ," & , & $"$ & 0.101 \\
\hline
\end{tabular}

Maximum height $=$ initial figure $+23 \%$

Change in glycogen content.

\begin{tabular}{c|c}
\hline Remarks & $\begin{array}{c}\text { Glycogen } \\
\%\end{array}$ \\
\hline $\begin{array}{c}\text { Before adrenalin injection } \\
\text { Left hind leg muscles }\end{array}$ & 0.107 \\
3 hours after adrenalin & \\
injection & \\
Right hind leg muscles & 0.052 \\
Lirer & 0.048 \\
Heart muscle & -
\end{tabular}

(Diminution of glycogen in muscle

$50 \%)$

\section{Experiment $\mathrm{V}$.}

Rabbit 3. Male, fasting from January 26 to February 1. Water ad ]ibitum, initial weight 1.2 kilos, final weight 1.0 kilos. $\Lambda 13.80$ p.m. February 1,1 c.c. adrenalin ( $1: 1000)$ subcutaneously injected.

\begin{tabular}{|c|c|c|c|c|c|}
\hline & \multicolumn{4}{|c|}{ Time of taking blood } & Filood sugar \\
\hline \multirow{2}{*}{\multicolumn{5}{|c|}{$\begin{array}{l}\text { Pefore adrenalin injection } \\
10 \text { nimutes anter arentin injetion }\end{array}$}} & 0.093 \\
\hline & & & & & 0.107 \\
\hline 15 & ", & $"$ & , & , & 0.138 \\
\hline 25 & $"$ & $"$ & $"$ & " & 0.144 \\
\hline 30 & $"$ & , & $"$ & " & 0.166 \\
\hline 60 & ", & ", & , & ", & 0.180 \\
\hline 90 & $"$ & " & 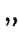 & ", & 0.140 \\
\hline 120 & ", & ", & " & $"$ & 0.146 \\
\hline 180 & $n$ & " & " & " & 0.133 \\
\hline
\end{tabular}

Maximum heicht of blood sugar is about twice of initial height.
Change in glyougen content

\begin{tabular}{c|c}
\hline Remarks & $\begin{array}{c}\text { Glycigen } \\
\% 6\end{array}$ \\
\hline $\begin{array}{c}\text { Before adrenalin injection } \\
\text { Left hind leg muscles }\end{array}$ & 0.183 \\
3 hours after adrenalin & \\
injection & \\
Right hind leg muscles & 0.042 \\
Ijiver & 0.080 \\
Heart muscle & 0.250
\end{tabular}

(Diminution of glycegen in muscle 


\section{Experiment VI.}

Rabbit 4. Male, fasting from January 26 to February 3. Water ad libitun, initial weight 1.47 kilos, final weight 1,2 kilos. At 1.30 p.m. February 3,1 c.c. adrenalin (1:1000) subcutaneously injected.

\begin{tabular}{|c|c|c|c|c|c|}
\hline & \multicolumn{4}{|c|}{ Time of taking blood } & $\begin{array}{c}\text { Blood sugar } \\
0_{0}\end{array}$ \\
\hline \multirow{2}{*}{\multicolumn{5}{|c|}{$\begin{array}{l}\text { Before adrenalin injection } \\
10 \text { mintes afer adriadin injectios }\end{array}$}} & 0.111 \\
\hline & & & & & 0.120 \\
\hline 15 & , & 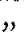 & , & ton & 0.127 \\
\hline 30 & ", & " & ", & $"$ & 0.120 \\
\hline 45 & $"$ & 3 & ", & 7 & 0.166 \\
\hline 60 & $"$ & " & $"$ & $"$ & 0.177 \\
\hline 90 & " & $"$ & ", & $n$ & 0.200 \\
\hline 120 & " & " & , & " & 0.172 \\
\hline 180 & $"$ & $"$ & $"$ & " & 0.135 \\
\hline
\end{tabular}

Change in glycogen content.

\begin{tabular}{c|c}
\hline Remarks & $\begin{array}{c}\text { Glycogen } \\
\%\end{array}$ \\
\hline Before adrenalin injection & \\
Left hind leg muscles & 0.121 \\
3 hours after adrenalin & \\
injection & \\
Right hind leg muscles & 0.036 \\
Liver & 0 \\
Heart muscle & 0.100
\end{tabular}

Maximum ralue of blood sugar is about twice of the initial ralue.

(Diminution of glycogen in muscle

$70 \%$

Experiment VII.

Rabbit 5. Female, fasting from February 5 to February 13. Initial weight 2.2 kilos, final weight 1.78 kilos. At 9.30 a.m. February 13 , 1 c.c. adrenalin $(1: 1000)$ subcutaneously injected.

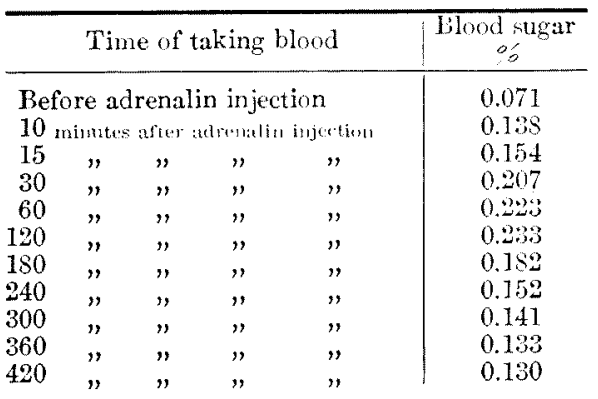

Hence maximum height is about three and onethird times of the initial height.

Change in glyeogen content.

\begin{tabular}{c|c}
\hline Remarks & $\begin{array}{c}\text { Glycogen } \\
\text { \%ó }\end{array}$ \\
\hline Before adrenalin injection & \\
Left hind leg muscles & 0.076 \\
3 hours after adrenalin & \\
injection & \\
Right hind leg nuscles & 0.014 \\
Liver & 0.044 \\
Heart muscle & 0.172
\end{tabular}

(Diminution of glycogen in muscle $82 \% 0)$

\section{Experiment VIII.}

Rabbit 6. Male, fasting from February 5 to February 13. Initial weight 2.1 kilos, final weight 1.5 kilos. At 9 a.m. February 13,1 c.c. adrenalin $(1: 1000)$ subcutaneously injected.

\begin{tabular}{|c|c|c|c|c|c|}
\hline \multicolumn{5}{|c|}{ Time of taking blood } & Blood sugar \\
\hline \multirow{3}{*}{\multicolumn{5}{|c|}{$\begin{array}{l}\text { Before operation } \\
\text { Immediately after operation } \\
15 \text { mintes affer abutaliu injection }\end{array}$}} & 0.094 \\
\hline & & & & & 0.125 \\
\hline & & & & & 0.165 \\
\hline 30 & $"$ & $"$ & $n$ & $"$ & 0.170 \\
\hline 60 & $"$ & $\because$ & $"$ & $"$ & 0.185 \\
\hline 120 & $"$ & $"$ & $"$ & $"$ & $0.2 * 35$ \\
\hline 180 & $"$ & ", & ", & $"$ & $0 .: 345$ \\
\hline 240 & $"$ & $"$ & 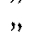 & $"$ & 0.381 \\
\hline 860 & $"$ & $"$ & $"$ & $"$ & 0.241 \\
\hline
\end{tabular}

Maximum height of blond sugar comer up to about four times of initial figure.
Change in glycogen content.

\begin{tabular}{c|c}
\hline Remarks & $\begin{array}{c}\text { Glycogen } \\
\%\end{array}$ \\
\hline $\begin{array}{c}\text { Before adrenalin injection } \\
\text { Left hind leg muscles }\end{array}$ & $0.2 \pm 0$ \\
; hours after adrenalin & \\
injection & \\
Right hind leg muscles & 0.051 \\
Liver & 0 \\
IIeart muscle & 0.102
\end{tabular}

(Dininution of glycogen in muscle $7706)$ 
As the summary of the result gained from the experiments, Experiments I-VIII are tabulated as follows (Table I).

\section{Table I.}

(Summary of Experiment I to VIII.)

\begin{tabular}{c|c|c|c}
\hline \multirow{2}{*}{$\begin{array}{c}\text { Number of } \\
\text { experiment }\end{array}$} & \multicolumn{3}{|c}{ Blood sugar \% } \\
\cline { 2 - 4 } & Initial height & $\begin{array}{c}\text { Maximum height } \\
\text { after adrenalin } \\
\text { injection }\end{array}$ & Difference \\
\hline & 0.133 & 0.163 & $+22.6 \%$ \\
2 & 0.117 & 0.222 & $+90 \%$ \\
3 & 0.120 & 0.241 & about twice \\
4 & 0.117 & 0.144 & $+23 \%$ \\
5 & 0.093 & 0.180 & about twice \\
6 & 0.111 & 0.200 & about three times \\
7 & 0.071 & 0.238 & about four tines \\
8 & 0.094 & 0.381 &
\end{tabular}

As shown in the table, in any case of the fasting animals a remarkable hyperglycemia was its result, and as to the rate of the increase of blood sugar, its minimum was 22.6 per cent of the initial blood sugar height and its maximum went up even about four times as high as the initial height.

And next comes the summary of the change of the glycogen content in the muscle before and after the adrenalin injection (Table II).

TABle II.

\begin{tabular}{c|c|c|c}
\hline \multirow{2}{*}{$\begin{array}{c}\text { Number of } \\
\text { experiment }\end{array}$} & Glycogen (per cent) \\
\cline { 2 - 4 } & Before injection (L) & After injection (R) & Difference \% \\
\hline \multirow{2}{*}{1} & 0.125 & 0 & 100 \\
2 & 0.258 & 0.155 & 40 \\
3 & 0.666 & 0.289 & 65 \\
4 & 0.107 & 0.052 & 50 \\
5 & 0.183 & 0.042 & 77 \\
6 & 0.121 & 0.036 & 70 \\
7 & 0.076 & 0.014 & 82 \\
8 & 0.220 & 0.051 & 77
\end{tabular}

So, compared with the glycogen content in the muscle before the adrenalin injection, that after the injection shows the diminution of 40 100 per cent, the average being 67.6 per ent.

Hence it follows that the adrenalin injection develops a very remarkable hyperglycemia in fasting animals on one hand, and at the same time it causes a phenomenal diminution of glyougen in muscle on the other. 
Before these results made me conclude that adrenalin injection into fisting animal mobilizes the glyeogen in musele and consequently hyperglycemia is produced, I performed the following control experiments.

1. For the purpose of ascertaining to what degree the glyeogen in the liver can be diminished by fasting, I estimated the glycogen content in the liver, in the muscle, and at times in the heart muscle, after the fasting period of 7-14 days. Its results are represented in the Table III :- that is, while both the skeletal muscle and the heart muscle still maintained the glycogen content in considerable quantities, the glycogen content in the liver diminished very remarkably and its amount was by far smaller than the formers. Heneeforth it might be somewhat a premature decision to ascribe the adrenalin hyperglycemia in fasting animals exclusively to the muscle glycogen, withont giving further thought to the influence of the glycogen in liver, because the glycogen in the liver exceedingly decreased but yet it was found not completely disappeared (Table III).

\section{Thase III.}

Influence of fasting upon glycogen content in the liver.

\begin{tabular}{|c|c|c|c|c|c|c|}
\hline \multirow{2}{*}{$\begin{array}{c}\text { Number of } \\
\text { rabbit }\end{array}$} & \multirow{2}{*}{$\begin{array}{l}\text { Days of } \\
\text { fasting }\end{array}$} & \multicolumn{2}{|c|}{ Body weight (grms.) } & \multicolumn{3}{|c|}{ Glyoogen content $(0,0)$ in } \\
\hline & & Initial & Final & Liver & Muscle & Heart \\
\hline 13 & 7 & 1210 & 830 & 0.112 & 0.243 & 0.303 \\
\hline 14 & 8 & 10,30 & 770 & 0 & 0.200 & 0.293 \\
\hline 15 & 9 & 1410 & 1080 & 0.133 & 0.182 & 0.132 \\
\hline 16 & 10 & 1340 & 1100 & 0 & 0.083 & 0.332 \\
\hline 17 & 14 & 1120 & 860 & 0.053 & 0.238 & 0.241 \\
\hline 18 & 12 & 1420 & 1020 & 0.083 & 0.249 & - \\
\hline
\end{tabular}

For all of that, if we talke inte cumicleration the fact that the glyeogen in the muscle after the allenalin injertion showod a remarkable diminution as compared with that before the injection, it may be quite reasonable and proper for us to assert that the principal cause of the adrenalin hyperglycemia in this case was the breaking down of the glycogen in the muscle.

Of course, here it might be andmissible that carbuhydrate can be male from protein, yet to try to make use of it to explain the results above mentioned is nomewhat very circumlocutory.

2. In the course of the said experiments on fasting animals, with the view of estimating the glyougen content in muscle before the injection, 
the specimen of muscle was taken, and then before another specimen of muscle after the adrenalin injection was taken, in most cases three hours had elapsed since the hard operative procedure of amputation was carried on. For this reason, in order to observe the influence of the operative procedure and the lapse of time upon the glycogen content in muscle of fasting animals without adrenalin injection, after three hours the estimation was made of the glycogen content in the muscles of both hind legs of rabbits which had been kept fasting for three days, and then the comparison was done, too.

In these cases just as in the other cases, for the purpose of aroiding errors from the rariation of the glycogen contents in the muscles with different names, all possible pieces of muscle in the hind leg were collected and minced with the masticator. Then they were stirred up so well that they became perfectly even like pap. Out of this material, some part was taken as a specimen of the muscle for the estimation of glycogen content.

The result was that the difference was $7-14$ per cent, the average being 11.3 per cent. It is a matter of course that this newly-gained result can never account for so big a diminution as 67.6 per cent in the glycogen of the muscle that was observed in the case of the adrenalin injection (Table IV).

\section{TABLE IV.}

Infuence upon the glycogen content in muscle excised by operative procedure and lapse of time after amputation.

\begin{tabular}{|c|c|c|c|c|c|c|}
\hline \multirow[b]{2}{*}{$\begin{array}{l}\text { Number of } \\
\text { rabbit }\end{array}$} & \multirow[b]{2}{*}{$\begin{array}{l}\text { Days of } \\
\text { fasting }\end{array}$} & \multicolumn{2}{|c|}{ Body weight (grms.) } & \multicolumn{3}{|c|}{ Glycogen (per cent) in muscle } \\
\hline & & Initial & Final & $\begin{array}{l}\text { Beginning } \\
\text { (left hind } \\
\text { Jeg) }\end{array}$ & \begin{tabular}{|c|}
8 hours \\
later (right \\
hind leg)
\end{tabular} & $\begin{array}{c}\text { Difference } \\
0_{0}^{\prime}\end{array}$ \\
\hline 23 & 8 & 1750 & 1600 & 0.140 & 0.125 & -14 \\
\hline 84 & 8 & 1170 & 1020 & 0.220 & 0.198 & -10 \\
\hline 25 & 3 & 1220 & 1100 & 0.150 & 0.140 & -7 \\
\hline
\end{tabular}

3. Furthermore, the two specimens of the glycogen in muscle which were compared before and after the adrenalin injection into the fasting animals, had been taken from the two different sides of the body, the right side and the left. So observation was made as to what the difference is between the glyeogen rontent in the corresponding mustes on the different sides of the body.

In 1908, Ma ignon made use of dogs in his experiments. Acording to what he found, even in the corresponding muscles, if they are from 
different sides, then the glycogen content are not the same. Especially the variation is more distinct in well-fed animals than in emaciated ones. And after a certain period of fasting, the difference between the glycogen amount in the corresponding muscles on both sides of the body diminishes. To give a fuller account, in well-fed animals the difference was 21-36 per cent. In dogs after fasting for 4-5 days, it was $13-21$ per cent, and in the cases of dogs, which had been fasting for 8-14 days, the difference of 12-21 per cent was found (C. f. Tables V and VI).

\section{TABLe V.}

Variation of glycogen content in muscles of different parts of body of fasting animals (Maignon's experiments No. I)

\begin{tabular}{c|l|ll}
\hline Days of fasting & Name of muscle & \multicolumn{2}{l}{ Glycogen (per cent) } \\
\hline \multirow{2}{*}{4 days } & Temporal & Right & 0.134 \\
& & I dayt & 0.161 \\
& Semitendinosus & Right & 0.441 \\
5 days & Semimentranosus & Left & 0544 \\
& & Right & 0.679 \\
5 days & Semitendinosus & Left & 0.708 \\
& Right & 0.221 \\
4 days & Biceps femoris & Left & 0.200 \\
& & Right & 0.220 \\
5 days & Biceps femoris & Left & 0.255 \\
& & Right & 0.316 \\
& & Left & 0.400
\end{tabular}

Minimum difference 13\% Maximum difference $21 \%$

\section{TABLE VI.}

(Maignon's experiments No. $I I$ )

\begin{tabular}{|c|c|c|c|}
\hline Days of fasting & Name of muscle & \multicolumn{2}{|c|}{ Glycogen (per cent) } \\
\hline 13 days & Biceps femoris & $\begin{array}{l}\text { Right } \\
\text { Left }\end{array}$ & $\begin{array}{l}0.810 \\
0.275\end{array}$ \\
\hline 14 days & $"$ & $\begin{array}{l}\text { Right } \\
\text { Left }\end{array}$ & $\begin{array}{l}0.280 \\
0.255\end{array}$ \\
\hline$s$ days & $"$ & $\begin{array}{l}\text { Right } \\
\text { Left }\end{array}$ & $\begin{array}{l}0.205 \\
0.160\end{array}$ \\
\hline 9 days & $"$ & $\begin{array}{l}\text { Right } \\
\text { Left }\end{array}$ & $\begin{array}{l}0.125 \\
0.135\end{array}$ \\
\hline 12 days & $"$ & $\begin{array}{l}\text { Right } \\
\text { Left }\end{array}$ & $\begin{array}{l}0.225 \\
0.180\end{array}$ \\
\hline
\end{tabular}

Mininum difterence 12\% Maxinum difference 2196 
In this research, in like wise, applied the same experiment to rabbit that had been fasting for 5-9 days (Experiment IX-XI).

\section{Experiment IX.}

Rabbit 26. Male, fasting 7 days. Initial weight 1.2 kilos., final weight 0.83 kilo., water ad libitum.

\begin{tabular}{l|c|c|c}
\hline \multirow{2}{*}{ Region } & \multicolumn{2}{|c|}{ Glycogen (per cent) } & Difference \\
\cline { 2 - 3 } & Right \% & Left $\%$ & \\
\hline Muscles in back & 0.243 & 0.229 & 10 \\
Muscles in chest & 0.237 & 0.260 & 10 \\
Muscles in arm and shoulder & 0.230 & 0.242 & 5 \\
Muccles in thigh & 0.250 & 0.233 & 7
\end{tabular}

Mininum difference $5 \%$, maximum difference $10 \%$, average difference $8 \%$.

\section{Experiment $\mathrm{X}$.}

Rabbit 26. Female, fasting 5 days. Initial weight 1.2 kilos., final weight 1.1 kilos., water ad libitum.

\begin{tabular}{|c|c|c|c|}
\hline \multirow{2}{*}{ Region } & \multicolumn{2}{|c|}{ Glycogen (per cent) } & \multirow{2}{*}{$\begin{array}{c}\text { Difference } \\
\%\end{array}$} \\
\hline & Right \%ó & Left :ó & \\
\hline Muscles in back & 0.220 & 0.242 & 10 \\
\hline Muscles in chest & 0.214 & 0.199 & 7 \\
\hline Mucles in arm and shoulder & 0.190 & 0.218 & 15 \\
\hline Muscles in thigh & 0.235 & 0.275 & 18 \\
\hline
\end{tabular}

Minimum difference $7 \%$, maximum difference $18 \%$, average difference $12.5 \%$.

\section{Experiment XI.}

Rabbit 27. Male, fasting 9 days. Initial weight 1.4 kilos., final weight 1.0 kilo.

\begin{tabular}{l|r|r|r}
\multirow{2}{*}{ Region } & \multicolumn{2}{|c|}{ Glycogen (per cent) } & Difference \\
\cline { 2 - 4 } & Right \% & Left \% & $\%$ \\
\hline Muscles in back & 0.174 & 0.165 & 5 \\
Muscles in chest & $0.18 \%$ & 0.175 & 2.2 \\
Muscles in arm and shoulder & 0.167 & 0.183 & 8.8 \\
Muscles in thigh & 0.190 & 0.170 & 10.5
\end{tabular}

Minimum difference $2.2 \%$, maximum difference $10.5 \% 0$, average difference $6.4 \%$.

In a rabbit fasting for 5 days, the difference of $7-18$ per cent was observed between the right side and the left side muscles. In another rabbit fasting 7 days, the difference was $5-10$ per cent, while in the third 
animal after fasting for 9 days, it was from 2.2 per cent to 10.5 per cent.

Both in the result worked by Maignon and in the result of my own experiments, as the variation of the glycogen amount in the different muscles taken from the fasting animals was very small, it could not account for the great diminution of the glycogen in the muscles which was observed at the time of the adrenalin injection.

Hereupon, it may be affirmed that the adrenalin hyperglycemia developed in fasting animals is the result from the muscle glycogen mobilized by adrenalin injected.

\section{The Repeated Injections of Adrenalin in Fasting Rabbits.}

Concerning to the influence of the repeated injections of adrenalin upon the hyperglycemia and the glycosuria, Underhill and Closson, ${ }^{29}$ also Underhill ${ }^{30}$ reported the fict that the same dose of adrenalin at different times in the same animal causes a very different degree of glycosuria. Herter and Wakeman found that the glycosurie effect of adrenalin disappears in a few days.

Noel-Paton ${ }^{13}$ found that daily repetition of subcutaneous injection of adrenalin results a certain tolerance for adrenalin and that the animals can withstand an otherwise lethal dose of adrenalin. But the glycosuria was usually present. Velich $h^{31)}$ observed in frogs that the repeated injection was always followed by glycosuria as long as a good nutritional condition was kept. When the animals were fasted from the begimning of the experiments, in 5 to 6 days, glycosuria could no longer be resulted. He explained this fact with the entire loss of the glycogen in liver.

Polla $\mathrm{k}^{329}$ made a most detailed research in this problem and found that through the repeated injection of adrenalin into rabbits which were fasted from the start of experiments, glycosuria usually disappeared in few days, and obscrved the hyperglycemia, however, was developed and reached as high as 0.29 to 0.4 per cent. He considers that this was due to a certain alteration in the permeability of the kidney, so that sugar failed to pass into the urine. Kuriyama $a^{333}$ reported that adrenalin hyperglycemia was not markedly modified by daily repetition of the drug injection in well nourished animals. In the fasting period, the intensity of hyperglycemia sometimes becomes a little lower; in most of the cases, however, it is as high as in the fecding period. 
In my present cxperiment, with view of consuming the glycogen which had already been existing in the body the rabbits had been kept fasting for 3-4 days before the adrenalin injection. The animals was kept fasting with a subcutaneous injection of 1-2 c.e. adrenalin every day. Water was given ad libitum. The urine was collected daily and the sugar in it was determined by the Pary-Kumagawa-Suto's method.

The blood sugar was estimatel by Bang's miero-method every day morning.

At the termination of the experiment, the rabbits were killed by a blow on the neck. The glyeogen of liver and skeletal muscles was determined by Pflüger's method. The results are shown in Experiment XII, XIII, XIV, XV and XVI.

From the results it is obvious that even in one and the same animal the degree of glycosuria developed by the same dose of adrenalin is so variable at different times that the variation ranges from 5 per cent to the disappearance of the sugar in the urine. The adrenalin hyperglycemia in fisting animals seemed to be the same as in the normal animals.

With regard to the glyogen content of the liver, there was pronoune-

\section{Fxperiment XII.}

Rabbit 45 . Female, weight 1.8 kilos, fasting and adrenalin injection, measured water ad libiturn.

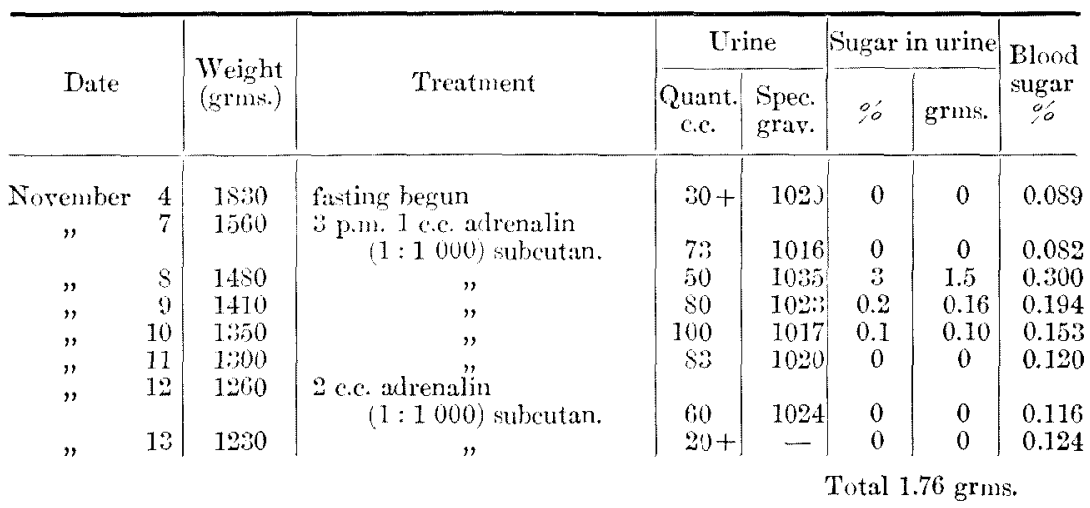

Total amount of adrenalin injected 9 c.c. $=9 \mathrm{mgrms}$.

November 13, 10 a.m. the rabbit was killed with blows on the neck.

Glycogen content in liver $0.264,0$.

Glycogen content in muscle 0.12200 . 


\section{Experiment XIII.}

Rabbit 46. Female, weight 1960 grms, fasting, water ad libitum.

\begin{tabular}{|c|c|c|c|c|c|c|c|c|}
\hline \multirow{2}{*}{\multicolumn{2}{|c|}{ Date }} & \multirow{2}{*}{$\begin{array}{l}\text { Weight } \\
\text { (grms.) }\end{array}$} & \multirow{2}{*}{ Treatment } & \multicolumn{2}{|c|}{ Urine } & \multicolumn{2}{|c|}{ Sugar in urine } & \multirow{2}{*}{$\begin{array}{l}\text { Blood } \\
\text { sugar } \\
\%\end{array}$} \\
\hline & & & & $\begin{array}{c}\text { Quant. } \\
\text { c.c. }\end{array}$ & $\begin{array}{l}\text { Spec. } \\
\text { grav. }\end{array}$ & $\%$ & grms. & \\
\hline ovember & 4 & 1960 & fasting begun & 38 & 1012 & 0 & 0 & 0.102 \\
\hline$"$ & 7 & 1850 & 3 p.m. adrenalin $(1: 1000)$ & & & & & \\
\hline & & & 1 c.c. subcut & $\begin{array}{l}40 \\
45\end{array}$ & 1014 & 0 & 0 & 0.094 \\
\hline$"$ & 8 & 1780 & $"$ & 40 & 1040 & 5 & 2.25 & 0.347 \\
\hline$"$ & $\begin{array}{r}9 \\
10\end{array}$ & 1 & $"$ & 70 & 1020 & 1 & 0.70 & 0.211 \\
\hline$"$ & 10 & 10 & $"$ & 102 & 1016 & 0.3 & 0.36 & 0.200 \\
\hline$"$ & 11 & 1650 & $"$ & 30 & - & 0.3 & 0.09 & 0.190 \\
\hline$"$ & 12 & 1600 & " & 160 & 1013 & 0.4 & 0.64 & 0.184 \\
\hline " & 13 & 1570 & $\begin{array}{l}9 \text { a.m. } 1 \text { c.c., \& } 4 \text { p.m. } \\
1 \text { c.c. adrenalin subcutan. }\end{array}$ & 80 & 1016 & 0.6 & 0.48 & 0.217 \\
\hline$"$ & 14 & 1450 & ", & 90 & 1017 & 0.4 & 0.36 & 0.176 \\
\hline$"$ & 15 & 1 & $"$ & 80 & 1016 & 0.3 & 0.24 & 0.188 \\
\hline$"$ & 16 & 1420 & $"$ & 100 & 1020 & 0.5 & 0.50 & 0.162 \\
\hline 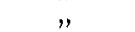 & 17 & 1350 & $"$ & 93 & 1017 & 0.4 & 0.37 & 0.130 \\
\hline$"$ & 18 & 1330 & ," & 70 & 1014 & 0.5 & 0.35 & 0.144 \\
\hline 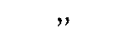 & 19 & 133 & $"$ & 100 & 1012 & 0.2 & 0.20 & 0.139 \\
\hline$"$ & 20 & 1310 & ", & 65 & 1016 & 0 & 0 & 0.136 \\
\hline$"$ & 21 & 1260 & " & 90 & 1014 & 0 & 0 & 0.132 \\
\hline
\end{tabular}

Total amount of adrenalin injected 24 c.c. $=24 \mathrm{mgrms}$.

Total $6.54 \mathrm{grms}$.

Norember 22, 10 a.m. the rabit was killed witl blows on the neck.

Glycogen content in liver $0.244^{\circ}$.

Glycogen content in muscle $0.198 \%$.

\section{Experiment XIV.}

Rabbit 47. Female, fasting and adrenalin injection, measured water ad libitum.

\begin{tabular}{|c|c|c|c|c|c|c|c|c|}
\hline \multirow{2}{*}{\multicolumn{2}{|c|}{ Date }} & \multirow{2}{*}{$\begin{array}{l}\text { Weight } \\
\text { (grms.) }\end{array}$} & \multirow{2}{*}{ Treatment } & \multicolumn{2}{|c|}{ Urine } & \multicolumn{2}{|c|}{ Sugar in urine } & \multirow{2}{*}{$\begin{array}{c}\text { Blood } \\
\text { sugar } \\
o 6 \\
(9 \mathrm{am} .)\end{array}$} \\
\hline & & & & $\begin{array}{c}\text { Quant. } \\
\text { c.c. }\end{array}$ & $\begin{array}{l}\text { Spec. } \\
\text { grar. }\end{array}$ & 96́ & grms. & \\
\hline November & 24 & 256. & fusting begun & - & - & - & - & 0.099 \\
\hline Decenber & 1 & 2220 & $\begin{array}{l}\text { p.m. adrenalin }(1: 1000) \\
1 \text { c.c. subcutan. }\end{array}$ & 80 & 1018 & 0 & 0 & 0.101 \\
\hline " & 2 & 2210 &, & 85 & 1028 & 1.8 & 1.53 & 0.146 \\
\hline " & 3 & 2100 & ", & 50 & 1087 & 1.4 & 0.7 & 0.199 \\
\hline , & 4 & 2000 & , & 60 & 1080 & 1.0 & 0.6 & 0.130 \\
\hline$"$ & 5 & 1980 & , & 83 & 1029 & 0.5 & 0.42 & 0.144 \\
\hline$"$ & 6 & 1920 & ", & 80 & 1027 & 0.3 & 0.24 & 0.122 \\
\hline$"$ & 7 & 1900 & $"$ & 40 & 1000 & 0.2 & 0.08 & 0.113 \\
\hline$"$ & 8 & 1820 & $"$ & & & & & \\
\hline$"$ & 9 & 1800 & at 10 a.m. the rabbit was & 75 & 1022 & 0 & 0 & 0.120 \\
\hline$"$ & 10 & $175)$ & $\begin{array}{l}\text { at } 10 \text { a.m. the rabbit was } \\
\text { killed by blowing on his } \\
\text { neck. }\end{array}$ & & & & & \\
\hline
\end{tabular}

Total amount of adrenalin injected 9 c.c. $=9 \mathrm{mgrms}$.

Total 3.57 grms.

Glycogen content in muscle $0.172 \%$.

Glyengen content in liver $0.232 \%$.

Total amount of glucose excreted $3.57 \mathrm{grms}$. 


\section{Experiment XV.}

Rabbit 48. Female, normally fed and adrenalin injection, measured water ad libitum.

\begin{tabular}{|c|c|c|c|c|c|c|c|c|}
\hline \multirow[b]{2}{*}{ Date } & & \multirow{2}{*}{$\begin{array}{l}\text { Weight } \\
\text { grms. }\end{array}$} & \multirow[b]{2}{*}{ Treatment } & \multicolumn{2}{|c|}{ Urine } & \multicolumn{2}{|c|}{ Sugar in urine } & \multirow{2}{*}{$\begin{array}{c}\text { Blood } \\
\text { sugar } \\
\% \\
9 \mathrm{a} . \mathrm{m} .\end{array}$} \\
\hline & & & & $\begin{array}{l}\text { Quant. } \\
\text { c.c. }\end{array}$ & $\begin{array}{l}\text { Spec. } \\
\text { grav. }\end{array}$ & 96 & grms. & \\
\hline December & 1 & 1970 & $\begin{array}{l}3 \text { p.m. } 1 \text { c.c. adrenalin } \\
\text { subcutan. }\end{array}$ & 100 & 1012 & 0 & 0 & 0.110 \\
\hline$"$ & $\stackrel{2}{2}$ & 1930 & $"$ & 80 & 1040 & 2.0 & 1.6 & 0.182 \\
\hline$"$ & 3 & 1870 & $"$ & 110 & 1030 & 1.5 & 1.6 & 0.213 \\
\hline$"$ & 4 & 1830 & $"$ & 70 & 1026 & 0.8 & 0.56 & 0.190 \\
\hline$"$ & 5 & 1800 & $"$ & 60 & 1024 & 0.4 & 0.24 & 0.165 \\
\hline$"$ & 6 & 1710 & " & 80 & 1028 & 0.3 & 0.24 & 0.160 \\
\hline$"$ & 7 & 1680 & & 30 & 1025 & 0 & 0 & 0.124 \\
\hline$"$ & 8 & 1660 & $\begin{array}{l}1 \text { p.m. killed by striking } \\
\text { on the neck. }\end{array}$ & - & - & 一 & - & 0.122 \\
\hline
\end{tabular}

Total amount of adrenalin 7 c.e. $=7$ mgrms.

Total 4.24

Total amount of sugar excreted 4.24 grms.

Glycogen content in muscle $0.213 \%$.

Glycogen content in liver $0.449, \%$.

\section{Experiment XVI.}

Rabbit 49. Male, normally fed and adrenalin injection.

\begin{tabular}{|c|c|c|c|c|c|c|c|c|}
\hline \multirow[b]{2}{*}{ Date } & & \multirow{2}{*}{$\begin{array}{l}\text { Weight } \\
\text { grms. }\end{array}$} & \multirow[b]{2}{*}{ Treatment } & \multicolumn{2}{|c|}{ Urine } & \multicolumn{2}{|c|}{ Sugar in urine } & \multirow{2}{*}{$\begin{array}{l}\text { Blood } \\
\text { sugar } \\
\% \\
9 \text { a.m. }\end{array}$} \\
\hline & & & & $\begin{array}{c}\text { Quant. } \\
\text { c.c. }\end{array}$ & $\begin{array}{l}\text { Spee. } \\
\text { grav. }\end{array}$ & $\%$ & grans. & \\
\hline December & 1 & 1820 & $\begin{array}{l}3 \text { p.m. } 1 \text { c.c. adrenalin } \\
\text { subcutan. }\end{array}$ & 180 & 1014 & 0 & 0 & 0.110 \\
\hline$"$ & $\begin{array}{l}2 \\
3\end{array}$ & $\begin{array}{l}1780 \\
1750\end{array}$ & $"$ & $\begin{array}{l}150 \\
120\end{array}$ & $\begin{array}{l}1032 \\
1028\end{array}$ & $\begin{array}{l}1.6 \\
1.2\end{array}$ & $\begin{array}{l}2.8 \\
1.4\end{array}$ & $\begin{array}{l}0.208 \\
0.212\end{array}$ \\
\hline$"$ & 4 & 1640 & $"$ & 100 & 1019 & 1.0 & 1.0 & 0.177 \\
\hline$"$ & 5 & 1730 & $"$ & 80 & 1024 & trace & & 0.170 \\
\hline$"$ & 6 & 1700 & $"$ & 120 & 1018 & 0.3 & 0.36 & 0.120 \\
\hline 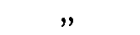 & 7 & 1680 & $"$ & 72 & 1021 & 0.2 & 0.14 & 0.123 \\
\hline ", & $\begin{array}{l}8 \\
0\end{array}$ & 1540 & 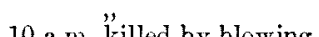 & 77 & 1024 & 0 & & 0.130 \\
\hline & 9 & 1520 & $\begin{array}{l}10 \text { a.n. killed by blowing } \\
\text { on the neek. }\end{array}$ & & & & & \\
\hline
\end{tabular}

Total 6.20

Total amount of adrenalin 8 c.c. $=8$ mgrms.

Total amount of glucose excreted 6.2 grms.

Glycogen content in nuscle $0.192 \%$.

Glycogen content in liver $0.707 \%$.

ed increasing in fasting rabbits. These result harmonized with those of Pollak and Kuriyama.

According to Pollak's statement, the content of muscle glycogen of 
the rabbits, which were fasted and injected repeatedly with adrenalin, was reduced almost to zero.

Kuriyama, on the contrary, found no change in muscle glycogen.

In my experiment, the glycogen content in the muscle is increased as well as in the liver. Thus the repeated injections of adrenalin, in a certain suitable condition, cause a glycogen storage in liver and muscle. There were many explanations of this fact, but any definit evidence is lacking.

III. Is there any Difference in Resistance to Adrenalin between the Liver Glycogen and the

Glycogen in Muscle?

According to the report of $\mathrm{Bang}^{26)}$ even in fasting animals adrenalin hyperglycemia was produced, but it was rather slower in breaking out than the case of well fed animals.

The following experiment of mine, however, reveals a contrary result that is, there is hardly observed any remarkable difference between these, two (Table VII).

\section{TaBdeE VII.}

Subcutaneous injection of 1 c.c. adrenalin $(1: 10000)$.

\begin{tabular}{|c|c|c|c|c|c|c|c|c|}
\hline \multirow{2}{*}{\multicolumn{3}{|c|}{ Time of taking blood }} & \multicolumn{6}{|c|}{ Blood sugar $\%$} \\
\hline & & & \multicolumn{3}{|c|}{ (a) Well-fed rabbits } & \multirow{2}{*}{$\begin{array}{c}\text { (b) } \\
\begin{array}{l}\text { I. } 8 \\
\text { days } \\
\text { fasting }\end{array}\end{array}$} & \multicolumn{2}{|c|}{ Fasting rabbits } \\
\hline & & & I & II & III & & $\begin{array}{l}\text { II. } 5 \\
\text { days } \\
\text { fasting }\end{array}$ & $\begin{array}{l}\text { III. } 7 \\
\text { days } \\
\text { fasting }\end{array}$ \\
\hline \multirow{2}{*}{\multicolumn{3}{|c|}{$\begin{array}{l}\text { Before injection } \\
10 \text { minutes after injection }\end{array}$}} & 0.126 & 0.090 & 0.110 & 0.094 & 0.071 & 0.093 \\
\hline & & & 0.192 & 0.137 & 0.150 & 一 & 0.138 & 0.107 \\
\hline 15 & & $"$ & 0.207 & 0.144 & 0.172 & 0.165 & 0.154 & 0.138 \\
\hline 30 & & $"$ & 0.231 & 0.181 & 0.211 & 0.170 & 0.207 & 0.166 \\
\hline 60 & & $"$ & 0.278 & 0.240 & 0.273 & 0.188 & 0.223 & 0.180 \\
\hline 120 & & $"$ & 0.285 & 0.340 & 0.286 & 0.235 & 0.233 & 0.146 \\
\hline 180 & & $"$ & 0.284 & 0.279 & 0.280 & 0.345 & 0.182 & 0.133 \\
\hline
\end{tabular}

IV. Experiment on Phosphorus Poisoned Rabbits.

It was rather in cases of acute poisoning that Frank and Is a a $\mathrm{c}^{20)}$ used phosphorus poisoned rabbits in their experiments. I, however, applied subcutaneous injection of phosphor in a small quantity every day 
so that I might bring the animals to the chronic poisoning state. The phosphorus for my injection was a solution of $0.5 \%$ of it in olive-oil, and 0.5 c.c. -1 c.c. $(0.0025-0.005 \mathrm{grm}$.) of the solution was the dose for one injection (Experiment XVII-XXI).

\section{Experiment XVII.}

Rabbit 40. Female, weight 1880 grms., medium flesh.

\begin{tabular}{|c|c|c|}
\hline Date & Phosphorus injection & Blood sugar $\%$ \\
\hline March 10 & 1 c.c. subcutan & 0.094 \\
\hline , $\quad 11$ & 0.5 & 0.086 \\
\hline " 12 & 0.5 & 0.081 \\
\hline$" 13$ & 0.5 & 0.063 \\
\hline 14 & 0.5 & 0.060 \\
\hline
\end{tabular}

Total amount of phophorus injected 3 c.c. $=15 \mathrm{mgrms}$.

March 14, 2 p.m. killed by knocking at the neck.

Glycogen in liver $0.116 \%$.

Glycogen in muscle $0.072 \%$

\section{Experiment XVIII.}

Rabbit 41. Male, weight 2000 grms.

\begin{tabular}{|c|c|c|}
\hline Date & Phosphorus injection & Blood sugar \%ó \\
\hline $\begin{array}{cc}\text { March } & 18 \\
, & 19 \\
, & 20 \\
, & 21 \\
, & 22 \\
, & 28\end{array}$ & $\begin{array}{l}1 \text { c.c. subcutan } \\
0.5 \\
0.5 \\
-0.5 \\
0.5 \quad "\end{array}$ & $\begin{array}{l}0.083 \\
0.079 \\
0.073 \\
0.068 \\
0.070 \\
0.063\end{array}$ \\
\hline
\end{tabular}

Total amount of phosphorus injected 3 c.c. $=15 \mathrm{mgrms}$.

March 23, 11 a.m. killed by knocking at the neck.

Glycogen in muscle $0.09 \% 0^{\circ}$.

Glycogen in liver $0.06 \%$.

\section{Experiment XIX.}

Rabbit 42. Female, weight 1980 grms.

\begin{tabular}{|c|c|c|}
\hline Date & Phosphorus injection & Blood sugar $\%$ \\
\hline $\begin{array}{cc}\text { March } & 10 \\
, & 11 \\
, & 12 \\
" & 13 \\
" & 14 \\
, & 15 \\
, & 16\end{array}$ & $\begin{array}{lc}0.5 & \text { c.c. subcutan } \\
0.5 & " \\
0.5 & " \\
0.5 & " \\
0.5 & " \\
0.5 & " \\
1.0 & "\end{array}$ & $\begin{array}{l}0.103 \\
0.092 \\
0.080 \\
0.080 \\
0.072 \\
0.065 \\
0.053\end{array}$ \\
\hline
\end{tabular}

Total amount of phosphorus injected 4 c.c. $=20 \mathrm{mgrms}$.

March 16, 3 p.m. killed with a blow at the neck.

Glycogen in liver $0.04 \%$.

Glycogen in muscle $0.066 \%$ 
When the diminution of the blood sugar gets so low as $0.05 \%$, rabbits become suddenly weak, even to the death. Therefore I availed myself of the opportunity when the blood sugar decreased to about $0.06 \%$ in experimenting the adrenalin hyperglycemia.

\section{Experiment XX.}

Rabbit 43 . Male, weight 1900 grms, good nutrition.

\begin{tabular}{|c|c|c|}
\hline Date & Phosphorus injection & Blood sugar :ó \\
\hline April 29 & - & 0.100 \\
\hline ,, 30 & 0.5 c.c. subcutan & 0.092 \\
\hline May 1 & $0.5 \quad "$ & 0.100 \\
\hline$\# 2$ & 0.5 & 0.093 \\
\hline , 3 & 0.5 & 0.083 \\
\hline$" 4$ & 1.0 & 0.083 \\
\hline$" 5$ & - & 0.080 \\
\hline$" 6$ & 1.0 & 0.078 \\
\hline$" 7$ & - & 0.070 \\
\hline$" 8$ & 1.0 & 0.068 \\
\hline$n$ & 1.0 & 0.062 \\
\hline
\end{tabular}

Total amount of phosphorus injected 6 c.c. $=30 \mathrm{mgrms}$.

May 10. 1 c.c. adrenalin subcutan.

\begin{tabular}{r|c} 
Time of taking blood & Blood sugar \% \\
\hline Before adrenalin injection & 0.060 \\
15 minutes after injection & 0.056 \\
30 " " " " " " " & 0.062 \\
45 & 0.060 \\
48 " " & 0.064
\end{tabular}

Glycogen in muscle before injection $0.03 \%$.

Glycogen in muscle after injection $0.02 \%$.

Experiment XXI.

Rabbit 44. Male, weight 1750 grms. Medium flesh.

\begin{tabular}{|c|c|c|c|}
\hline Date & \multicolumn{2}{|c|}{ Phosphorus injection } & Blood sugar \%ó \\
\hline May 1 & $0.5 \mathrm{c}$ & eous injection & 0.098 \\
\hline$\Rightarrow \quad 1$ & 0.5 & " & 0.100 \\
\hline$" 2$ & 0.5 & $"$ & 0.094 \\
\hline, 2 & 一 & & 0.089 \\
\hline$" 2$ & 0.5 & $n$ & 0.083 \\
\hline$" 2$ & - & & 0.080 \\
\hline$n \quad 2$ & 0.5 & , & 0.072 \\
\hline$\Rightarrow 2$ & 1.0 & " & 0.070 \\
\hline 112 & 0.5 & ", & 0.065 \\
\hline 127 & - & & 0.064 \\
\hline$\Rightarrow 2$ & 0.5 &, & 0.065 \\
\hline
\end{tabular}

Total amount of phosphorus injeeted 4.5 c.c. $=22.5 \mathrm{mgrm}$. 
May 29, 1 c.c. adrenalin subcutaneous injection.

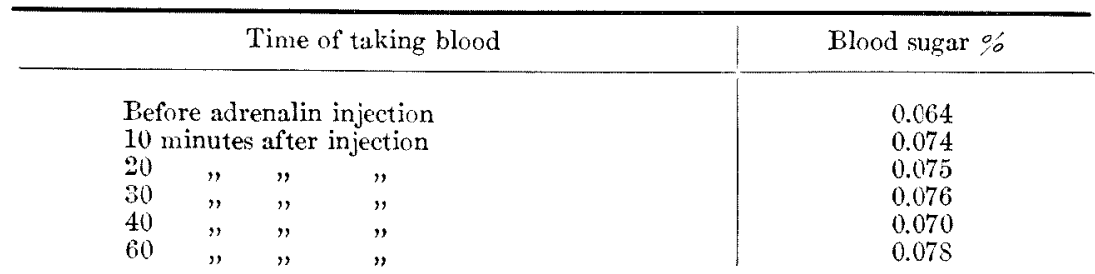

Glycogen in muscle before adrenalin injection $0.100 \%$.

Glycogen in muscle after adrenalin injection $0.088 \%$.

As the results of the foregoing experiments it is made clear, that not only the liver-glycogen but also the muscle glycogen greatly decreases owing to the phosphorous poisoning, and the adrenalin hyperglyecmia is produced only very inconspicuously. The change of the glycogen content in muscle before and after the injection is very slight.

\section{CONCLUSIONS.}

As the results of the experiments described hitherto, the following conclusions are drawn.

1. Even in the animals, whose glycogen in liver was made to disappear almost entirely through starvation, hyperglycemia is very conspicuously developed by adrenalin.

2. The repeated injections of adrenalin to fasting rabbits develop glycosuria and hyperglycemia to a high degree therein, and the glycogen contents both in the liver and in the muscle are about as much as that in normal animals.

3. There is no difference of resistance to adrenalin betwcen the glycogen in liver and the glycogen in muscle.

4. In phosphorus poisoning rabbits, the glyeogen content in muscle and in liver decreases greatly and adrenalin hyperglycemia is exceedingly inconspicuous.

5. In short, it has been made very clear that the glycogen in muscle, too, is subjected to the mobilization by adrenalin.

\section{Biblography.}

(1) F. Blum, Dtsch. Arch. klin. Med., 1901, 71, 146.

(2) F. BI um, Pfliiger's Arch., 1902, 90, 617.

(3) G. Zuelzer, Berl. klin. Wochenschr., 1901, 38, 1209. 
(4) L. Metzger, Müch. med. Wochenschr., 1902, 49, 478.

(5) C. A. Herter and A. N. Richards, N. Y. Med. News, 1902, 80, 201. (Cit. in Centralbl. f. d. med. Wissensch., 1902, 40, 347$)$.

(6) C. A. Herter and A. J. Wakeman, Virchow's Arch., 1902, 196, 479.

(7) C. H. Vosburgh and A. N. Richards, Am. Journ. Physiol., 1908, 9, 35.

(8) K. S. I wanoff, Zentralbl. f. Physiol., 1905, 19, 891.

(9) J. J. R. Macleod and R. G. Pearce, Am. Journ. Physiol., 1911-12, 29, 419.

(10) G. Zuelzer, Perl. klin. Wochenschr., 1907, 44, 474.

(11) G. Zuelzer, Verh. d. Kong. f. inn. Med., 1907, 24, 258.

(12) E. Starkenstein, Ztschr. f. exp. Path. u. Therap., 1912, 10, 78.

(13) D. N. Paton, Journ. of Physiol., 1908, 29, 286.

(14) Eppinger, Falta and Rudinger, Ztschr. f. klin. Med., 1908, 66, 1.

(15) Eppinger, Falta and Rudinger, Ibid., 1909, 67, 380.

(16) A. J. Ringer, Proc. Soc. Exp. Biol. and Med., 1909-10, 7, S.

(17) M. Do yon and N. K a reff, Compt. rend. Soc. Biol., 1904, 56, 66.

(18) B. Wolownik, Virchow's Arch., 1905, 180, 225.

(19) W. Falt a and J. G. Priestley, Berl. klin. Wochenschr., 1911, 48, 2102.

(20) E. Frank and S. Is a ac, Ztschr. exp. Path. U. Therap., 1910, 7, 326.

(21) Michaud, Verh. d. Kong. f. inn. Med., 1911, 28, 561.

(22) T. Oka, Tohoku Journ. of Exp. Med, 1922, 3, 206.

(23) Z. Gat in-Gruzewska, Comp. rend. Acad. Scien., 1906, 142, 1165.

(24) K. Agardschanianz, Biochem. Ztschr., 1907, 2, 148.

(25) E. Starkenstein, Ztschr. f. exp. Path. u. Therap., 1912, 10, 78.

(26) I. Bang, Der Blutzucker, Wiesbaden 1913, 89.

(27) G. Momose, Tokyo Igakukwai Zasshi, 1914, 29, 903. (Jap.)

(28) F. Maignon, Journ. de Physiol. et de Path. géner, 1908, 10, 203.

(29) F. P. Underliill and O. E. Closson, Am. Journ. Physiol., 1906-07, 17, 42.

(30) F. P. Underhill, Journ. biol. Chem., 1911, 9, 13.

(31) A. Velich, Virchow's Arch. 1906, 184, 345.

(32) L. Pollak, Arch. exp. Path. u. Pharm., 1909, 61, 149.

(38) S. Kuriy ama, Journ. Biol. Chem., 1918, 34, 269. 